\title{
Foreign Direct Investment (FDI), Government Reform, and Their Role in Economic Development and the Rise of the Middle Classes in East and Southeast Asia
}

\section{Sajjad Kaveh Shaldehi*}

Free Sociologist in Islamic Republic of Iran

\section{Hadi Noor}

University of Gilan, Islamic Republic of Iran

\section{Arya Shafeghat Roodsari}

Imam Khomeini University of Nowshahr, Islamic Republic of Iran

\section{Shukoofeh Goodarzinezhad}

Tehran University of Science and Technology, Islamic Republic of Iran

\section{Behnam Goodarzinezhad}

Mashal Gostar TAHA Company, Islamic Republic of Iran

\begin{abstract}
Since the 1990s, East and Southeast Asian countries have experienced significant economic growth, leading to the expansion of the middle classes. Some scholars have attributed this economic development to cultural and political factors such as technocrat leaders, ethnic tolerance, or even Confucianism. Other researchers have only mentioned economic variables, such as free market, regional unions, and export-oriented policies. This paper does not rule out the role of these factors in the economic development of those regions, and by using a combined approach based on recent data, the authors argue that attracting foreign direct investment (FDI) and government reforms have been the most important factors influencing economic growth as well as the significant expansion of the middle classes in East and Southeast Asian societies.
\end{abstract}

Keywords: Middle class; foreign direct investment; government reform; economic development

\footnotetext{
*Corresponding email: sajjadkaveh@ymail.com
} 


\section{Introduction}

After centuries of isolation from the developments in Western Europe and the United States, East and Southeast Asia ${ }^{1}$ experienced rapid industrialization during the 1950s and 1960s, paving the way for the emergence of tiger economies, including in Hong Kong, Singapore, South Korea, Taiwan, China, Indonesia, Malaysia, Philippines, Thailand, and Vietnam. Emerging economies in East and Southeast Asia will dominate the middle class and consumerism in the coming decades. In 2015, for the first time in 300 years, the number of middle classes in these regions equaled that of the European-American. It is estimated that by 2021 there will be more than 2 billion middle-class families in the region - just 670 millions of them in China (Kharas \& Gertz, 2010, p. 33). As of 2009, there were only 500 million middleclass households in East and Southeast Asia, and it is now estimated that this number will increase six times in the next 20 years, or 3.2 billion people (See Table 1). In other words, the Pacific's share of the global middle class will increase from one-fourth in 2009 to two-thirds by 2030, while the share of North America and Europe will fall from 54\% to 21\% (Kharas \& Gertz, 2010, p. 37)

Table 1. Size of Middle Class by Region: 2009, 2020, 2030

Millions of people and global share (percent)

\begin{tabular}{|l|l|l|l|l|l|l|}
\hline Region & \multicolumn{3}{|l|}{2009} & \multicolumn{2}{l|}{2020} & 2030 \\
\hline North America & 338 & $(18)$ & 333 & $(10)$ & 322 & $(7)$ \\
\hline Europe & 664 & $(36)$ & 703 & $(22)$ & 680 & $(14)$ \\
\hline Central and South America & 181 & $(10)$ & 251 & $(8)$ & 313 & $(6)$ \\
\hline Asia Pacifica & 525 & $(28)$ & 1.740 & $(54)$ & 3.228 & $(66)$ \\
\hline Sub-Saharan Africa & 32 & $(2)$ & 57 & $(2)$ & 107 & $(2)$ \\
\hline $\begin{array}{l}\text { The Middle East and North } \\
\text { Africa }\end{array}$ & 105 & $(6)$ & 165 & $(5)$ & 234 & $(5)$ \\
\hline World & 1.845 & $(100)$ & 3.249 & $(100)$ & 4.884 & $(100)$ \\
\hline
\end{tabular}

(Kharas \& Gertz, 2010, p. 39)

East and Southeast Asia hope to accommodate two-thirds of the world's middle class by 2030, or about $\$ 3.2$ billion (The Nation, 2014). These regions are hosting the largest and the most dynamic consumers in the first step of their expenditures demand houses and apartments. They can afford their children's fees and health care insurance. The most important thing is that these new corps of spenders, unlike their Western counterparts, are not in debt for expenditures. As Peter Wong says:

It is expected that the population in Asia will nearly reach 5.3 billion up to 2050. Millions of them are being classified as middle class, and an American $20^{\text {th }}$-century dream with consumers gaining developing disposable income will turn to an Asian $21^{\text {st }}$-century dream. Demand for houses, smartphones, and financial services will increasingly come from east (Wong, 2017).

Significant economic success and the growth of the middle classes in East and Southeast Asian countries, especially in the second half of the twentieth century, have encouraged many researchers and social scientists to study and explain the causes of these successes. Meanwhile, the standard

\footnotetext{
${ }^{1}$ In this article by referring to East and Southeast Asia we mean eight countries of People's Republic of China, Japan, South Korea, North Korea, Taiwan, Hong Kong, Macau, and Mongolia, as well as ten ASEAN member states including Brunei, Cambodia, Indonesia, Laos, Malaysia, Myanmar, the Philippines, Singapore, Vietnam, and Thailand (For a further discussion see also: Purrestami, 2013).
} 
cultural features of these societies have led some thinkers to use Weber's approach to emphasize the importance of cultural factors (religion, politics, systems of value) in the development of East and Southeast Asian countries. This paper argues that a combined approach is needed to explain industrial development and economic growth in these regions, especially since the 1990s. This is because neither Weber's approach nor the economic approach alone can provide a proper understanding for the rapid economic growth and middle classes emerging in those areas.

\section{Literature Review}

The relationship between culture and the economic system of society, scientifically, was first studied in the early twentieth century by Max Weber (Weber, 2016). Weber's thought was mainly concerned with the influence of Protestantism on the emergence and evolution of modern capitalism. Inspired by Weber, several later writers such as Daniel Lerner (1958), David McClelland (1961), Evert Hagen (2013), and Alex Inkeles (1974) have emphasized the importance of cultural values in achieving industrialization and development in the Third World. Thinkers with a Weberian approach to economic development in East and Southeast Asia generally point to the following factors: political leaders, ethnic tolerance, developmental nationalism, the pluralization of different levels of society, and Confucianism.

Adrian Leftwich has explored economic growth in East and Southeast Asia over the past 30 years and discovered a unique feature among these countries' governments, calling them national development-oriented governments. In general, he measures the model of such a government in five indicators: a group of decisive development-oriented elites, an emerging civil society; simultaneous repression and legitimacy of the state; sound economic bureaucracy; and systematic fight against corruption (Leftwich, 2000, p. 86). He writes about the ASEAN countries:

The common denominator of all the leaders of these countries, who were mostly military, is the shift from ideology to pragmatism towards the development of the country. These countries have used elites regardless of their differences of opinion and put them at the forefront of achieving development, with a result-oriented approach and with a focus on extreme discipline (Leftwich, 2000, p. 164). ${ }^{2}$

In their article, "The Causes of Economic Development in Southeast Asia," Naqibzadeh and Sadeghizadeh argue that increasing ethnic tolerance and ethnic acceptance have been essential factors in accelerating economic development in the East and Southeast Asia regions. They argue that the acceptance of Chinese minorities in East and Southeast Asia has been the region's engine of development. They say the Chinese control vast fortunes that have nothing to do with their population in the destination countries. In Malaysia, for example, while the Chinese make up 30 percent of the population, they own 61 percent of the country's economy. In Indonesia, 3.5 percent of the population and 73 percent of the country's economy, in Thailand 10 percent of the population and 81 percent of the country's economy, and the Philippines only 2 percent of the Chinese control half of the country's economy. Naqibzadeh and Sadeghizadeh go so far as to say that East and Southeast Asia economies are, in a sense, rented by Chinese people, and that the main people in these countries are focused on public administration (Naqibzadeh and Sadeghizadeh, 2009, p. 338).

In a study entitled "Development of the World Economy," Herman Kahn has studied the intellectual and cultural roots of the development of countries such as South Korea, Taiwan, and

\footnotetext{
${ }^{2}$ For a more detailed discussion on the role of government in East and Southeast Asian countries' economic development, see Cumings,2007; Schibotto, 2015; and Lajcika, 2017.
} 
Singapore, and he attributed the success of these countries and other countries in the region to the existence of a culture of economic development. He considers the primary indicators of economic growth in East and Southeast Asia to be a set of cultural values. He considers them in four areas: Family socialization, which guarantees moderation, education, skills acquisition, and seriousness about homework, work, and family; Tendency to accompany and help the group, regardless of what the group is based on; and respect for social hierarchy and its nature (Glazer, 1999).

Some researchers point to the concept of developmental nationalism in the Pacific region, which has unique characteristics (see, for example, Hassall, 1991; Tokolyova, 2017; Duara, 2018). Duara, for example, argues that this nationalism, unlike the French and German types, is not based on a shared history, nor a typical race, but on a single goal, which is to achieve development. He thus calls it the third-way nationalism, or developmental nationalism (Duara, 2018, p. 16). As part of the value approach, Jinguo also points to the role of Confucianism in creating developmental attitudes in East and Southeast Asia countries. He writes:

The confucianism perception of the world, individual and social life, which is very similar to the capitalist worldview, has in practice helped to achieve a form of capitalist development in East Asian countries (Jinguo, 2000, p. 128).

Although Huntington himself is aware of the importance of cultural factors in development, he believes that culture in the social sciences is a deceptive concept, and its use is natural and deterrent. In his view, the use of social tools is dull yet dangerous because culture can be considered a storage category in some ways. According to Huntington, if none of the real causes can explain the apparent differences of societies in terms of the level of development, then the temptation arises to attribute such differences to culture. Thus, it is mostly unclear to what extent the culture is the source of political and economic differences among countries; therefore, cultural explanations are often inaccurate or repetitive (Mungiu \& Mindruta, 2002, p. 203).

Following the avoidance of cultural and political perspectives, some researchers, under the influence of Samir Amin (1976), Paul Baran (1958), Landsberg (1979), and Gold (1986), have used infrastructure approaches to explain the role of economic plans along with improvement in production and economic indicators in industrial growth in Asia. In this way, Holcombe, with regard to South Korea, says that policy makers in this country, with the purpose of industrialization and export growth, have resorted to economic measures such as choosing specific industries and providing them with various types of assistance, preventing fierce competition among industries, paving the way for private sectors, creating large enterprises and managing private consumption in order to accumulate capital. He points out that South Korea is one of the countries that first created the infrastructure for the development of exports in the country by adopting structural reform policies, and then implementing the policies to encourage exports based on those reforms. This country is currently one of the most successful export economies in the global market. It is one of the countries that has expanded its exports, reached its current position with careful planning, and created the necessary conditions for entering the global arena (Holcombe, 2013). ${ }^{3}$

John Jullens takes a free-market approach, and he believes that the main reason for the miracle of East and Southeast Asia was the conscious choice of a free market strategy (Jullens, 2014). For example, Hong Kong and Singapore openly chose the free market economy strategy and relied on market forces and the private sector to allocate financial and technological resources. For this reason, Kwong and Tang consider foreign trade, which is often complemented by domestic private investment

\footnotetext{
${ }^{3}$ For more researches about the economic policies of development in Malaysia and China, see Pattison,2016; Yusof, 2018; and
} Amadeo, 2019. 
in these countries, to be the leading sector or driving force of Hong Kong and Singapore (Kwong and Tang; 2018). In these countries, the economy is open to foreign trade and the international movements of the factors of production, namely, capital and labor. Since the market economy strategy usually indicates the active role of the private sector, they consider it in terms of capital, technology, trade, as well as the role of the private sector (Kwong \& Tang; 2018, also see Sarel, 2006).

In her study, "Factors Affecting Economic Convergence in the East Asian Region," Nahid Pourrestami addresses the issue of regionalism and the implementation of the same economic policies among East and Southeast Asia countries. She argues that these countries have set an interesting example of regional policy in recent decades and have achieved significant success and high economic growth. Examining the state of economic convergence between the 15 East and Southeast Asian countries during the years 1980-2012, Nahid Pourrestami concludes that the countries of Hong Kong, South Korea and Singapore have conditional convergence and the countries of Brunei, China, Indonesia, Malaysia, Thailand, Cambodia, Laos and Vietnam have an absolute convergence with the region's economic average. Using Flying Gees Pattern of Development, Pourrstrami highlighted factors such as the growing dependence of East and Southeast Asia industries on each other between 1985 and 2005, wage increases in Japan from the early 1980s, and the export of all countries to the region as essential factors in East and Southeast Asian economic convergence. (Pourrestami, 2013, for more researches on regional production chains, trade capacity with neighboring countries, and even dependence on the economic growth of major industrialized countries in the West, see Wang \& Wei, 2009, Kimura, 2011, Amini \& Shokrollahi, 2012, and Islami, 2014).

As can be seen, however, Proponents of Weber's approach argue that the main reason for the economic growth and emergence of the middle classes in East and Southeast Asia is due to political reforms and elements of specific value-cultural systems in these societies. Proponents of the economic approach, on the other hand, argue that economic policies and regional-globalist unions have played an essential role in the economic development of East and Southeast Asia countries. We would say neither Weber's approach nor the economic approach alone can explain the rapid economic growth of East and Southeast Asia and the emergence of new consumption patterns in these societies. This is because the new data and the economic realities of these regions indicate simultaneous changes in political measures and economic strategies. Weber's approach only considers changes in cultural systems and values to be the right way for the societies of East and Southeast Asia to evolve and, therefore, do not give much importance to economic variables. Proponents of the economic approach, while rightly emphasizing the role of economic variables, also neglect the importance of political decisions and the role of development-oriented leaders in East and Southeast Asia societies. Even in the realm of economics, they do not give first-class priority to important variables such as Foreign Direct Investment (FDI). While as Tokolyova points out, the pattern of economic growth in developing countries seems to be based on the continued absorption of foreign capital in various economic and service sectors to increase demand and, therefore, consumer growth (Tokolyova, 2017). As we show in this article, foreign direct investment in the form of financial and technological systems, especially since the 1990s, has played a significant role in the economic leap and growth of East and Southeast Asia. It has been the foundation of production and export capacities, reducing the unemployment rate and rising wages, and the emergence of new lifestyles and middle classes in these societies. Besides, the active involvement of national developmental governments in opening industrial doors and attracting foreign capital should not be neglected. As Rosenstein Rodan writes, the development-oriented system uses the market systematically as a tool for long-term economic transformation and to create conditions for the expansion and growth of industrial systems, without being tempted to usurp industrial and productive assets (Rodan, 1961, p. 237). 
In this paper, we argue that, based on the latest available economic statistics and data, the FDI flows into East and Southeast Asia economies, along with government intervention in attracting foreign capital and investing in social overhead capital, are important cultural and economic factors in explaining the economic success of East and Southeast Asia societies. In this regard, Rosen Stein Rodan's Big Push Model is used to point out the useful role of FDI. Although Rodan's view is considered as a classical theory of the modernization of developing societies, the Big Push Model is a good conceptual framework for combining Weber's approach and economic approach because it emphasizes the simultaneous importance of political reform and economic market orientation for the progress of developing societies. This theory has now shown significant compatibility, especially with the economic developments in East and Southeast Asia societies in recent decades.

\section{Conceptual Framework: Big Push Model}

In the early $1950_{s}$, the Big Push Model was presented by P.N. Rosenstein-Rodan. According to this model, developing societies must do their best in all aspects of the economy to get rid of the vicious circle of poverty in order to make a growth in other domains, increase production ability and demand. This model opposes incoherent and disordered investment, for there would not be a market to absorb new productions. In this case, it is necessary to create an income to increase demand, and it does not come true unless to invest in all aspects of the economy simultaneously (Nursky, 1971). Rosenstein believes that in developing countries the demand is limited owing to restricted markets; therefore, whenever various industries are being established simultaneously, each of them can meet the needs of others and in this case the total demand increases in a way that unproductive industries can survive (Nath, 1962). The Big Push Model means that in order to cope with the problems on the way of economic development in developing countries, a comprehensive investment plan is needed. Rosenstein believes that developing countries are generally in depression; then, to get rid of this, and benefiting from a continuous economic growth, they need a significant number of investments. He also believes that in these countries, government participation in economic activities is compulsory owing to the historical weakness of production powers and lack of a market mechanism to adjust fees. Government participation will remain until achieving economic growth and then replacing governmental section with private one. Continuous economic growth is similar to a plane on the airstrip. The plane before flying must get to the standard speed to fly. It is a necessary condition for a successful flight. In this opinion, gradual development and applying economic policies step by step will not help achieve successful economic growth. In order to achieve an ongoing economic growth, a minimum, multilateral, and dramatic investment is needed; otherwise, the plane will remain on the airstrip (Rosenstein-Rodan, 1961). For investment, a kind of project should be chosen to maximize social and economic profit. Therefore, applying more modern technology is mandatory for a thriving economy.

Rosenstein believes that a lack of economic substructure in developing countries leads to an uneconomical and ineffective investment. Transportation, electricity power, communication, and other substructure facilities need significant investments, but concerning the low level of saving, these kinds of investments cannot be accomplished. As he thinks, a comprehensive and vast investment plan is needed to accomplish investment projects in economic domains simultaneously. However, when forming various industries connected multilaterally via a limited amount of foreign investments, economic dynamic starts, and the economy in developing countries gets into economic growth (Rosenstein-Rodan, 1961). The main hypotheses of the Big Push Model are as follows:

1. In the first step of economic growth in countries, public investment is vital, and the lack of that may lead to instability of economic growth. 
2. Investment in different domains provides the necessary demands of other sections making each sector maintain its stable growth and therefore, will moderate the system's moderate growth.

3. Scheduled development will help to come out of the economy of developing countries from depending on raw resources and materials, which constitute the dominant economy of these countries, and by pushing them into industrialization, they will put the system in the correct position and avoid uncertainty resulted from traditional economy.

4. Government interference in the economy and investment in social overhead capital will be continued until the economy achieves stable growth. After that, the private sector will be substituted by the state sector.

\section{Research Method}

This paper's aim is to explain the reasons behind the significant economic growth and the emergence of middle classes in East and Southeast Asia countries. Since this article is a kind of statistical analysis, using meta-analysis and secondary-analysis techniques, trying to analyze the results from relevant literature and possibly modeling them to create a new pattern. For this purpose, sources and relevant data, international yearbooks, data from international institutions including DN and Work Bank, and reports from newspapers and magazines have all have been coded according to content and date of issue. These codes were then regulated based on our research's conceptual framework -Big Push Modeland the results transformed into a new style and pattern. In this article, we continuously refer to a conceptual framework in order to clarify research, providing interpretation and information of data in a chart.

\section{Foreign Direct Investment (FDI) Inflows Into East and Southeast Asia, Economic Growth, and the Newfound Middle Classes}

Foreign direct investment, either in the form of capital or technology, has played an essential role in the economic development of Asian countries over the last two decades (Roughneen, 2019; 2020). Asian developing economies, not only utilized foreign direct investment of neighborhood countries such as Japan, and new industrial economies such as Taiwan, but also they have been the center of OECD investment countries, especially the United States and Europe. Economic developments among East and Southeast Asia countries during 1991-1997, made to increased foreign direct investment up to 8\% $(390,651 m i l l i o n$ dollars) and has changed the region as the largest destination for foreign capitals (look at figure 1) (Diaconu, 2014, pp. 903-904). Foreign direct investment have been an important factor in export-oriented growth in East and Southeast Asia developing economies and as Thomsen mentions: "Trough such capital, the host economies from the agricultural economy and raw material utilization changed quickly into the major producers and exporters of manufactured product" (Thomsen, 199, p. 4). 


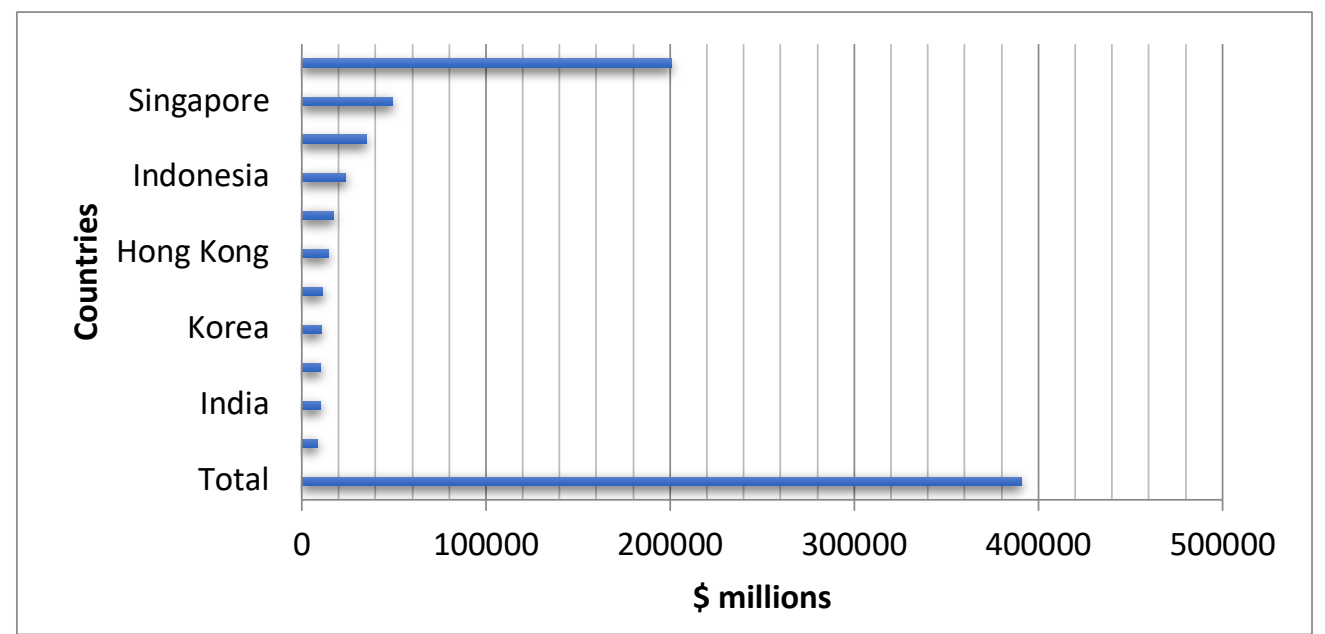

Figure 1. Total FDI inflows by Asian countries, 1990-97

(Author's Compilation, Thomsen, 1999, p. 7)

By the way, in the $21^{\text {st }}$ century, FDI inflows accelerated. Based on the Financier Worldwide Magazine report, the total volume of inflows capital for developing countries of East and Southeast Asia amounts to 382 billion dollars up to 2013, i.e., 4\% more than 2012 (Financier, 2015). More importantly, as the total FDI reduced 1.3 trillion dollars (13\%) all over the world in 2018, based on UNCTAD's world investment report in 2019, FDI increased in "developing Asia" to 512 billion dollars (4\%) and allocated 39\% of world total FDI, higher than America and Europe. (Look at table 2) (World Investment Report, 2019, p. 3).

Table2. FDI inflows, by region, 2017-2018

(Billions of dollars and percent)

\begin{tabular}{|l|l|l|l|}
\hline Region & $\mathbf{2 0 1 7}$ & $\mathbf{2 0 1 8}$ & Percent \\
\hline World & 1497 & 1297 & -13 \\
\hline Developed Economics & 759 & 557 & -27 \\
\hline Europe & 384 & 172 & -55 \\
\hline North American & 302 & 291 & -4 \\
\hline Developing Economics & 691 & 706 & +2 \\
\hline Africa & 41 & 46 & +11 \\
\hline Latin America and the Caribbean & 155 & 147 & -6 \\
\hline Asia & & & \\
\hline Transition Economics & 493 & 512 & +4 \\
\hline
\end{tabular}

(Author's Compilation, UNCTAD's World Investment Report, 2019)

As Financier Worldwide Magazine reports: "Despite the fact that western multinational companies have long been focusing on East and Southeast Asia as their primary destination for direct investment, we should consider the recent intensive investment as the result of local and regional market growth, abundance of natural resources in East and Southeast Asia and the strategic position of this region for export of manufactured products" (Financier, 2015). The survey of United Overseas Bank in 2014 showed that China, which is the home of more than 1.3 billion of Asian middle class, is the first destination for foreign companies (32\%), and countries like Malaysia (27\%), Singapore (24\%), Vietnam (24\%), and Indonesia (19\%) are placed in the next ranks (The Nation, 2014). Nevertheless, the 
orders mentioned above have comparatively changed up to 2017-2018. Among ten developing economies hosting the global FDI, China, Hong Kong, Singapore, Brazil, and India are in the first to fifth ranks (Look at Figure 2).

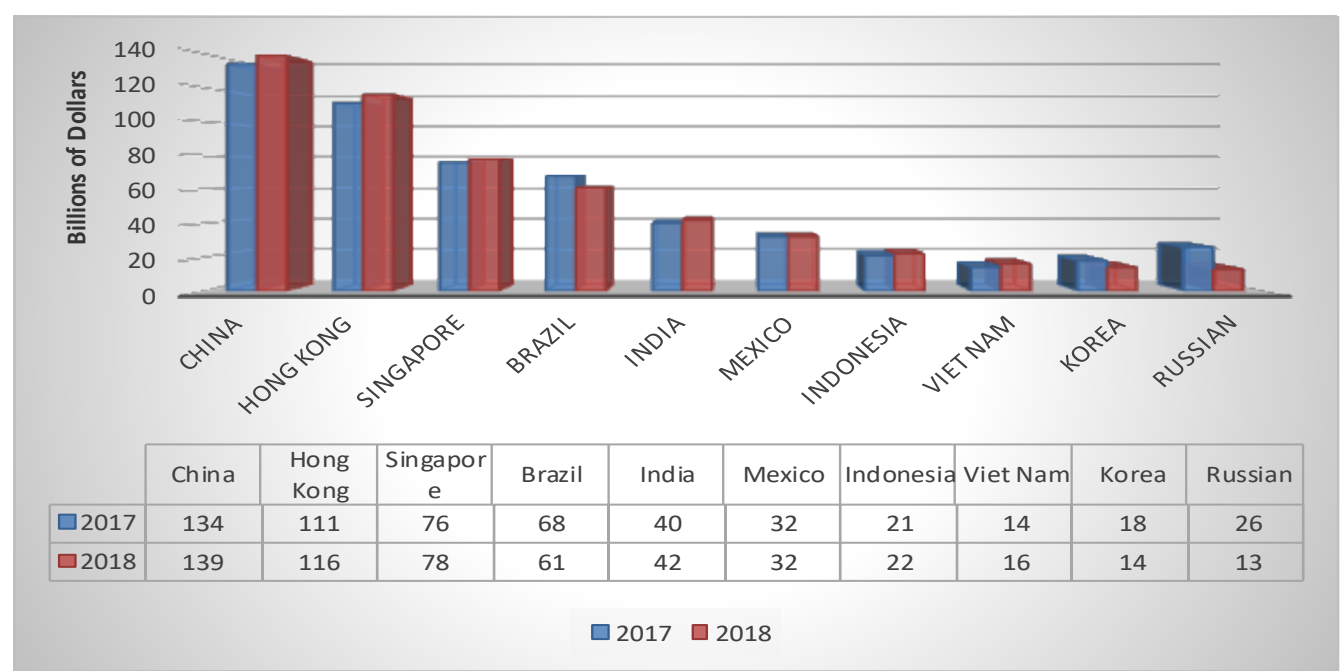

Figure2. FDI inflows, top 10 developing host economies, 2017 and 2018 (Billions of dollars) (Author Compilation, UNCTAD's World Investment Report, 2019)

For example, in China, FDI inflows made the country enter technology and technical skills with long-term advantages, but it connected local Chinese companies to financial markets. After decreasing FDI inflows in China in the base sector (agriculture), it has had significant growth in production and services sectors $(6 \%)$ since 2006 , which included $21 \%$ of all production companies inside China and $33 \%$ of total workers of China production sector (Seriatos, 2015, pp. 46-47). Therefore, FDI inflows and the relationship between Chinese local companies and the world markets have not only transformed the Chinese economy from a centralized economy to an important one, in which either the government or the market has played an important role, but have maintained the amount of China's economic growth at a positive level (6.9\% in 2017) (World Bank/China; 2017). As an example, in the industrial sector, China's Indices of Industrial Production in industries and mining domains decreased from 140.64 units in 2010 to 98 units in 2017. The indices in the production domain increased from 86.99 units in 2010 to 105.27 units in 2017, and in gas, electricity and water domains, from 195.66 units in 2010 to 203.52 units in 2017. In the foreign trade sector, China total volume of imports increased from 256,274 million dollars in 2010 to 259,266 million dollars in 2017 and the total volume of exports from 278,008 million dollars to 317,249 million dollars. In the import sector, whereas the most significant amount of imports was related to the sector of industrial and agricultural raw materials in 2017 (179,073 million dollars), but in experts sector, the largest amount of exports during the same period was included in other products sector (248,138 million dollars). Therefore, China's GDP increased from 1146,105 million dollars in 2010 to 572,767 million dollars in 2017 , and national income from 385,290 million dollars to 498,397 million dollars (for this total statistic and figures see Statistic Yearbook of Republic of China, 2017, pp. 14-20, 76-90, 94-99, 112-119). These figures show the useful role of FDI inflows in China's positive trade balance and opening of its industrial doors to international trade.

FDI inflows have also intensified in ASEAN member states and hits to the maximum, from 123 billion dollars in 2016 to 137 billion dollars in 2017 (see also ASEAN Economic Integration Brief, 2017, ASEAN Economic Integration Brief, 2019). FDI increased in Indonesia from 3.9 billion dollars in 2016 to 23.1 billion dollars (five times) in 2017, in Thailand to 9.1 billion dollars (three times), and in Philippine to 10 billion dollars (21\%). Total FDI inflows in four countries CLMV (Cambodia, Lao People's Democratic 
of Republic, Myanmar, and Vietnam) increased significantly to 23 billion dollars (21\%) in 2017 and allocated $17 \%$ of ASEAN total FDI. With FDI more than 14 billion dollars, Vietnam was the third big destination of FDI in ASEAN in 2017 and constituted 60\% of the total FDI of CLMV countries. In Brunei also FDI increased from 0.2 billion dollars in 2016 to 0.5 billion dollars in 2017 (ASEAN Investment Report; 2018: 4-5). ${ }^{4}$ We can see the impact of FDI inflows on the economic growth of ASEAN and the connection of markets of this region with the world capital in the positive balance of industries and trade sectors and the employment rate and amount of wages in ASEAN. In the domain of imports and exports of trade products, the total figure of ASEAN increased from 2001,443 billion dollars in 2010 to 2,574,288 billion dollars in 2017, which Singapore (700,946 million dollars) and Thailand (459,458 million dollars) have the most shares in it.

In the domain of imports and exports of trade services, the total amount of ASEAN increased from 440273.9 billion dollars in 2010 to 703143.1 billion dollars in 2017, which again Singapore (335529.5 million dollars) and Thailand (121459.6 million dollars) have the most share in it. In the trade services domain, the travel sector (202827.6 million dollars), transportation (168718 million dollars), and other business sections (164318.8 million dollars) have the most share in ASEAN income in 2017. Based on the number of manpower in 2017, Indonesia, by having 131,544 individuals ( $23.4 \%$ in the field of wholesale, retail, restaurant management and hoteling; $16.8 \%$ in public services; $13.3 \%$ in production; $4.6 \%$ in transportation and communications) ranked first. Vietnam with 54,823 individuals (17.3\% in the field of wholesale, retail, restaurant management and hoteling; $16.6 \%$ in production; $10 \%$ in public services; $3.7 \%$ in transportation and communications), and Philippines with 42,109 individuals ( $23.6 \%$ in the field of wholesale, retail, restaurant management and hoteling; $10.4 \%$ in public services; $8.1 \%$ in transportation, communications and transportation) ranked second and third, respectively. (Look at the total statistics and figures in ASEAN Statistics Yearbook; 2018: 27-37, 41-55, 59-118, 125-137). In general, the economy of ASEAN, inclusive of GDP growth from 1,927,874 billion dollars in 2010 to 2,765,798 billion dollars in 2017, has experienced a significant income of 26.6 billion dollars in 2017.

As indicated by the Big Push Model, in developing countries, due to limited markets, demand is limited, so revenue must be generated for sectors to increase demand. This is not possible except by investing simultaneously in all economic sectors. Therefore, whenever multiple industries are established simultaneously, each industry can meet the needs of other industries. Thus, aggregate demand increases in a way that stimulates the economic engine of these societies. So, when some interdependent industries are formed through a certain amount of foreign capital, economic mobility begins, and the economies of developing countries enter the path of economic growth.

According to this model, the continuous economic growth in East and Southeast Asia and the symmetrical and simultaneous investments in various socio-economic projects, such as real estates $(18 \%)$, oil, gas, and energy (12\%), airlines (10\%), structural and chemical materials $(9 \%)$, infrastructure and engineering $(6 \%)$, hotel and restaurant $(6 \%)$, drinks and foods $(3 \%)$, have created significant infrastructural improvements in urban areas, education, health, tourism, human development and communications for East and Southeast Asia societies (ASEAN Investment Report, 2018: 94; see also ASEAN, Brueckner, et al, 2017; Business Guide, 2018). As the ASEAN Focus reports: "because of income growth and the fast accumulation of capital in ASEAN, this region will experience one of the most rapid growth rate on urbanization among the central region of the world up to 2030" (ASEAN Focus, 2015).

\footnotetext{
${ }^{4}$ Up to 2017, multinational foreign companies such as Aeon (Japan), Continental (Germany), Ansell Ltd (Australia), and ASEAN companies such as Keppel (Singapore), Maybank (Malaysia), Petron crop (Philippine), Adaro energy (Indonesia), and ... in various industries and multiple investment expanded their presence in the region. Total cash investments of ASEAN multinational companies was 96 billion dollars in 2017, near to Cambodia GDP and Lao People's Democratic of Republic, or more than total investments of inside ASEAN between 2014-2017, and total assets of these companies increased from 700 billion dollars in 2010 to 1.1 trillion dollars (65\%) in 2017, it is near to GDP of 7 countries, i.e., Brunei, Cambodia, Lao People's Democratic of Republic, Malaysia, Myanmar, Philippine and Singapore, or about to FDI shares inside Singapore (the fifth great shares of world FDI) (ASEAN Investment Report, 2018, p. 89).
} 
They were attracting foreign capital in the fields of manufacture, industry and mining, energy, agriculture. It has expanded labor and increased wages in East and Southeast Asia and created a demand for more quality products and goods, improving the quality of people's lives in the form of middleclasses and consumers. In China, for instance, in 2017, from among 11,795 million of the Chinese workforce, 11,352 million people entered the labor market directly. From among these people, in the manufacturing industries sector, 3,045 million people were employed in the production sector and 901,000 people in construction. In the service industries sector, 1,875 million people were employed in the field of wholesale and retail trade and 832, 000 people in food services and welfare facilities. Therefore, not only monthly average income of China's labor force increased substantially between 2010-2017 (from 1,477 thousand dollars to 1,631 thousand dollars), but, final consumption per capita of the private sector increased from 324,001 million dollars in 2010 to 392,542 million dollars in 2017 (Statistical Yearbook of the Republic of China; 2017). A rise in disposable income in China and the country's household expenditures on such things as food, education, travel, health, and savings, along with lower mortality rates and higher life expectancy, have saved hundreds of millions of Chinese households from poverty and made middle class in China as one of the main actors in socio-economic policies in the region.

Table 3. Chinese Families Expenditures Along With Indices of Life Quality

\begin{tabular}{|c|c|c|c|c|c|c|c|c|c|}
\hline \multirow[b]{3}{*}{ year } & & & \multirow[b]{3}{*}{$\begin{array}{l}\text { Infant } \\
\text { mortality } \\
\text { rates }\end{array}$} & \multicolumn{5}{|c|}{ Per household (thousand US \$) } & \multirow[b]{3}{*}{$\begin{array}{l}\text { Outbound } \\
\text { visitors } \\
\text { (person- } \\
\text { times) }\end{array}$} \\
\hline & \multicolumn{2}{|c|}{$\begin{array}{l}\text { Life expectancy } \\
\text { (year) }\end{array}$} & & \multirow[b]{2}{*}{$\begin{array}{l}\text { Average } \\
\text { disposable } \\
\text { income }\end{array}$} & \multicolumn{3}{|c|}{ Expenditure } & \multirow[b]{2}{*}{ Savings } & \\
\hline & Male & Female & & & $\begin{array}{l}\text { Food, } \\
\text { beverage, } \\
\text { and } \\
\text { tobacco }\end{array}$ & Health & $\begin{array}{l}\text { Recreation, } \\
\text { culture, and } \\
\text { education }\end{array}$ & & \\
\hline 2010 & 76.13 & 82.55 & 4.2 & 29028 & 3814 & 3299 & 2523 & 6105 & 9415074 \\
\hline 2011 & 76.96 & 82.63 & 4.2 & 29636 & 3860 & 3479 & 2470 & 5841 & 9583873 \\
\hline 2012 & 76.43 & 82.82 & 3.7 & 30145 & 3923 & 3455 & 2378 & 6393 & 10239760 \\
\hline 2013 & 76.91 & 83.36 & 3.9 & 30753 & 3978 & 3580 & 2374 & 6341 & 11052908 \\
\hline 2014 & 76.72 & 83.19 & 3.6 & 31231 & 3911 & 3664 & 2362 & 6582 & 11844635 \\
\hline 2015 & 77.01 & 83.62 & 4.1 & 31494 & 3937 & 3730 & 2390 & 6699 & 13182976 \\
\hline 2016 & 76.81 & 83.42 & 3.9 & 32415 & 3994 & 3887 & 2378 & 7060 & 14588923 \\
\hline 2017 & - & - & 4.0 & 33258 & 4132 & 4039 & 2529 & 6765 & 15654579 \\
\hline
\end{tabular}

(Author Compilation, Statistical Yearbook of the Republic of China, 2017)

A survey accomplished by United Overseas Bank in 2014 showed that East and Southeast Asia aims to host two-thirds or about 3.2 billion of world middle classes, up to 2030. Frederick Chin, the head of this survey, announced that pay rises are an appropriate opportunity for those investors who can meet the needs, expectations, and consumption patterns of these families (The Nation, 2014). The growth of the middle class households in East and Southeast Asia, meanwhile, means that access to public services only is not enough for these people, and the quality of these services has also become important. Therefore, all of these people demand a high standard of housing (Benson, 2014, Woodward, 2003) motor vehicles (Ali \& Dadush, 2012), nourishment, energy, tourism (The Gold Coast Bulletin, 2012), education (Padilla, 2012; Fouad Khater, 2001), hygiene, and luxury products. Therefore, we can conclude that the considerable FDI process into Asia and the region's significant economic growth are as follows:

1. Admission of fast symmetrically and simultaneously process of FDI, especially from THE 1990s in various financial industrial and commercial sectors (significant investment).

2. Making income for active individuals in various sectors (economic movement). 
3. Making demand on other sectors and emerging large market on consumable products and commodities (economic growth and consuming-oriented individuals emerging).

4. Government Reforms

\section{Government Reforms}

Understanding the role of politics on improving and enforcing economic structures in Asia is very important. It is useful to assess politics, which probably had the most effects on the reconstruction of Asia economics. Understanding the role of the government in economic development in Asian countries is not simply a necessary issue in the case of direction and plans which are needed for the growth and prosperity of Asian markets. They should be regarded as one of the main bases of economic development and middle class growth alongside with FDI. Since the 1980s, Asian economic growth and prosperity have been dependent on the political framework's primary developments and its effects on personal improvement and development and poverty reduction (Hawes \& Liu, 1993). However, despite their institutional weakness, political reforms are widespread in the structures of most Asian states.

The reforms can range from introducing a floating exchange rate to replacing non-tariff with tariff barriers; from removing certain regulatory requirements to opening industries to competition, and to putting aside corrupt companies. The following are 10 items identified by the International Growth Center as political reforms among Asian states: maintaining financial discipline, prioritizing spending on health and education instead of spending on defense, introducing tax reforms in order to increase incomes, paying attention to interests and incomes of base market, maintaining a competitive exchange rate to boost exports, applying business policies based on deregulation of imports, introducing FDI incentive, supporting privatization, promoting competition through deregulation, defining and guaranteeing property rights (International Growth Center, 2010). Also, we should point to an essential and coherent group in the political structure of Asian countries whose duties are to analyze this fact that what should be done, how it should be done, and what the result should be Technocrats. Technocrats usually lack political power, and to transform their thought to policy, they need to persuade the political leaders to perform the reforms mentioned above. Although, there is no need that the leaders should merely be technocrat individuals, their personality should be in such a way that they realize the reforms as mentioned above, not technically but at least, intuitively, and try to execute them. Moreover, there should be a close and reliable working relationship between the leaders and technocrats.

In this regard, it is essential to mention the role of the Indonesia government in performing political reforms and commercial deregulation. In the middle of the 1980s, Indonesia performed comprehensive reforms that affected the amount of economic growth and almost neutralized the severe debt crisis in this country. In 1967-1982, because of correct economic management, oil incomes, and financial aids, Indonesia's economy improved significantly (Hill, 2013, p. 116). However, in the early 1980 s, the world economy speed retarded, and the oil price decreased from $30 \$$ to $10 \$$. Therefore, Indonesia's economy, which is three-fourth of its export products and two-thirds of its state incomes, depends on oil, gas, and their related products ran at a loss. Although in the early 1980s, the economy of Indonesia experienced little growth, since 1990s, the country's economic growth increased rapidly again. The government increases its incomes by taking prudent fiscal policies together with the immediate improvement of expenditures, especially in the ambitious plans for heavy industries and by performing a series of efficient financial reforms, This government action combines with a low inflation rate and receiving high financial endowments, led to macroeconomic stability in Indonesia and then adopted a comprehensive reform package in microeconomics. In the field of commercial policy, most 
of the non-tariff barriers were gradually removed, and by reducing and integrating tariffs, the exporters were placed in a free trade position with an efficient tax-free system.

Moreover, by performing a series of comprehensive reforms in customs, cumbersome and corrupt imports/export procedures were eliminated, obstacles to foreign investment were removed, the financial sector was deregulated, and stock markets were activated. Finally, many barriers to entry to the market were removed. In the center of these successful reforms, it is necessary to mention a cohesive and influential group of reformists called technocrats. Technocrats in Indonesia were known as Berkeley Mafia, since the beginning of Soeharto presidency, they occupied all significant economic and political positions, and despite lacking a major political party to support them, they had significant technical credentials. Most importantly, before Soeharto came to power, technocrats had a close relationship with him and had comprehensive supervision on successful stability and economic recovery of Indonesia in the second half of the 1960s. However, regional countries such as Japan and international organizations like the World Bank were prominent in the future stability and economic growth of Indonesia (Hill, 2013, p. 117).

In China, there is no doubt that the government of China has a central role in modernization and delivering this country to superior economic powers. The government of China played a significant role in implementing new and superior forms of economic planning in the economy and fiscal policy. It provided an integrated financial system in order to manage and supervise investment opportunities in China continuously. Nevertheless, between 1998-2000, while the share of state-owned enterprises in China fell from $39.2 \%$ to $6.1 \%$, the private sector experienced a $52.6 \%$ growth and the number of its labor force increased from 2.6\% in 1998 to $28.6 \%$ in 2007 (Jabbour \& Dantas, 2017, p. 800). We should relate the formation and development of the private sector in China to the formation of market-based economy. It must be noted that the government of China itself was also a major player in this development strategy in that the reduction on quantity of public sector was compensated by creating millions of jobs in urban and rural areas along with the rise of capitalist and domestic middle classes, which is functionally important for national and international strategy of China. The Chinese government achieved a unique combination of market mechanism and planning by the strategy of combining the market centralization and program multiplication, which has constituted China's developmental approach up to now. Moreover, the government has granted discretion to rural regions and industries. Therefore, passing from a planned centralized economy to a more flexible economy and the strategic process of major companies and banks combine needs reforms with improving the central mechanisms of macroeconomics (Hsu, 2016). Now, China is experiencing its developmental dynamism. In addition to having positive processes, it has a series of inequalities and contradictions in the form of environmental crises, social inequalities, and problematic issues. ${ }^{5}$

In Malaysia, the purpose of government in introducing New Economic Policy (NEP) in 1971 was to establish the middle class; a target that gradually developed in conjunction with the political economy. The purpose of government in NEP is to recreate the structuration in the society so that justice can be established between Malays and other ethnic groups by disengaging specific ethnic groups from predetermined jobs (Embong, 2002). In other words, the primary purpose of NEP was to re-structuralize the job distribution pattern in Malaysia. The simple philosophy of NEP resulted in designing of national development policy of NDP in 1991-2000 and the national vision policy of NVP in 2001-2010. By theses long-term plans in 1971, the government of Malaysia tried to establish middle classes and placing them as the mainstream of middle classes in Malaysia. At first, the government's conception of establishing

\footnotetext{
${ }^{5}$ Manuel Castells mentions that China has performed a series of economic reforms since 1978, which has effectively transitioned this country to a participatory economy and was competitive with a world trade network system. China's economic reforms have created significant individualism and independence in the field of consumption; and, in particular, resulted in a Chinese cultural revolution, the growth of the new middle class and consumerism in urban regions (Hayton \& Others,; 2015, pp. 8-9).
} 
middle classes was a vague impression of those who were ultimately responsible for political and social stabilization. For this reason, the government helped establish middle classes and strengthen the old middle classes' elements, i.e., landowners and business people. Nevertheless, during the 1980s and by choosing the massive industrialization strategy of Mahathir government, the government's aim changed to the new middle classes, i.e. the technical-vocational experts. In this case and by choosing the policy of economic privatization, the experiment of establishing new middle classes commenced selectively. Hence, establishing middle classes was one of Mahathir's commercial-industrial plans and the central policy. Then, in the early 1990s, this policy changed to strengthening the business middle classes, which transferred to a valuable tool to implement commercial-industrial plans (Torii, 2003, pp. 221-240).

Heffner (2015) finds a strong correlation between South Korean nationalist narration and the formation of the modern Korean middle class during the Park Chong Hei regime (1961-1979), so whatever was good for the government would be good for the middle classes, too. By effective economic policies and creating the Korean middle class, the Chong regime tried to move Korean toward a better future after decades of war, poverty, and destruction. Creating an urban middle class was a part of a more significant project of the new Korean economic perspective (Heffner, 2015, p. 32). However, due to the confrontation between the state middle class in Korea and neo-liberalism, as a new economic rationality that encompasses all aspects of social and economic life, the state middle class was gradually losing color, and until 1997, government interests and middle class had no longer compromised together (Heffner, 2015, p. 32). Therefore, the newfound middle class in Korea remained in a sporadic and heterogeneous space, which was expected to succeed without the government's support. In the viewpoint of Heffner, this newfound group could succeed well because its actors, like their former western counterparts and their new Asian counterparts, are now at least a member of a sports club, go to the café constantly, care a lot for plastic surgery and consider learning at least a foreign language as a social necessity (Heffner, 2015, pp. 39-40).

During the 1980s in India, the government changed parts of its economic policy and performed some reforms in which Indian economic capitals are now constituted around them (Gottschlich, 2011; Fernandes, 2006; Wessel, 2004). The government gradually abandoned the first ideals of self-sufficiency and opened the Indian economic gateway to foreign investors, which led to the remarkable growth of consumable goods in the Indian market (Hamel \& Tong, 2019). Today, economic capitals and the massive volume of consumable goods set new standards for Indian consumer preferences, and commodities that were previously out of reach are now considered acceptable to individuals as a basic necessity of life (Raka, 2008, pp. 128-129). In a field survey in the state of Gujarat, people were asked to mention their viewpoints about the fast changes in this region. Most of these people inevitably referred to "consumption" as a central part of the experience of modern life. So, Wessel concludes "When people concede that the cost of living has increased, they not only claim a gradual increase in the cost of daily necessities, but also consider raising the living standards that are now normal and usual." (Wessel, 2004, p. 97)

Finally, after an abominable experiment on centralized planning such as disastrous endeavors on nationalism and collectivism agriculture in Vietnam, the government selected the strategy of Doi Moi (renovation) in the sixth conference of the communist party in December 1986. The most important components of Dio Moi are as follows: increasing the interest rate, integration of the exchange rate, legalization of gold preservation, and decreasing deficits in the public sectors, omission of subsidies in public enterprises, and demobilization of half a million soldiers. They also include omission of public investment plans, price deregulation and omission of public procurement system, law legislation on enterprises rights, deregulation of FDI, free international trade and establishing trade zones (Hilll, 2013, p. 115). By the way, in the middle 1990s, because of Asian economic crisis (depression), the speed of government reforms retarded. However, in the late 1990s, he second phase of Doi Moi performed its 
purposes were more improvement of entrepreneur laws, more deregulation of trade and investment rules, and more reforms in public enterprises. Then, Vietnam has experienced considerable economic growth for one, and after that, in 2008, because of wrong political actions and world economic crisis, it re-experienced slow economic growth. Now, there is no doubt that Vietnam's economic growth is in a rapid course of growth again because of macroeconomic policy, industrial policy, and public reforms in the entrepreneurship domain (Pham, 2012).

So, political reforms and emerging technocrat and modernist governments have played an essential role in developing regional markets and economic prosperity to facilitate foreign investment domain and economic motivation and leap in the Asian region. In these countries, because of historical weakness of generative powers and lack of market mechanism for moderating prices, public companies, in economic activities, first removed the obstacles of economic growth and prosperity against productive enterprises. Then, by providing the necessary situation and safe competitive environment, they encouraged the foreign producing and investor companies to participate in investment of the basic and infrastructure sectors of the region. After that, the government, together with the continuous economic growth and stability of market mechanism in the region, reduced its interference in the economic sector and completed its role in the region's emerging economic power by providing the necessary situation to develop the private sector.

\section{Conclusion}

Mark Zakouni, JOC executive manager of official business information and data gathering agency, writes: "By 2030, there will be 207 billion new middle class and Asian consumer households accounting for $90 \%$ of the global middle class. These households will spend up to $\$ 30$ trillion, with very high disposable incomes. ... And of the 440 cities that provide half of GDP growth to the middle class by 2025, more than 300 will be in Asia." (Zakouni, 2014). As initially mentioned, by 2009, there were only 500 million middle-class households in East and Southeast Asia. It is now estimated that in the next 20 years the number of this class will grow six-fold, equivalent to 3.2 billion people, and East and Southeast Asia's share of the global middle class will grow from one-quarter in 2009 to two-thirds by 2030.

Thus, what are the reasons behind the immediate emergence of the middle classes in East and Southeast Asia and their rapid growth?

In this paper, Rosenstein Rodan's Big Push Model was used to find the answers to this question. For Rosenstein, developing countries can come out of the vicious circle of poverty at once, and under certain conditions, being on the path of long-term economic development. He believes that a lack of robust economic infrastructure in developing countries and the low level of savings in these countries will prevent their economies from the dynamism and going through productive stagnation. Also, scattered investments, step by step, will not solve the problem. Therefore, he recommends the developing countries should simultaneously follow the foreign direct investment in different sections so that with increasing economic dynamism and creating more revenues the demand for domestic production would be increased. To do this, the government's role as a facilitator of the conditions and creating a safe stage for economic activities is of utmost importance. Under these circumstances, there continue economic growth and development in developing countries.

As mentioned, the significant growth of middle-class families in East and Southeast Asia and the availability of domestic and international consumption, especially from the 1990s, are due to the foreign direct investment. Foreign direct investment, either in the form of budget or in the form of technology during the two last decades, has played a vital role in the economic growth of region's countries or sheds light on the path of economic growth. Host economies, through the absorption of such investments, quickly became the major producers and exporters of manufactured products. As trusted 
markets, in 2018, they accounted for $\$ 512$ billion of the world's total FDI, higher than the US and Europe. In China in 2017, for example, FDI, in addition to bringing technology, technical skills, and linking its economy to the resources of the global financial markets, boosted China's GDP to \$ 572767 million annually by generating mobility and revenue in the base, service, and manufacturing sectors and kept China's economic growth at a positive level (6.9\% in 2017). Also among the ASEAN member states, FDI flows have surged to their highest level, from \$ 123 billion in 2016 to $\$ 137$ billion in 2017, and given ASEAN's GDP growth from \$ 1927874 billion in 2010 to $\$ 2765798$ billion in 2017, the region economy experienced an impressive $\$ 26.6$ billion in 2017.

On the other hand, the existence of technocratic and modernist governments, despite institutional weaknesses, paved the way for the attraction of foreign investments, and security of regional markets. The government political reforms have covered a great domain and attracted foreign investment firms into the domestic market. In Indonesia, for example, the government increased its revenues by adopting prudent fiscal policies, along with immediate adjustments on expenditures -especially in ambitious plans for heavy industries and a string of efficient financial reforms. These measures, combined with low inflation and high financial earnings, led to macroeconomic stability in Indonesia. In Vietnam, the government was able to promote the country 's rank amongst the 10 top countries in the field of FDI, This was made possible through increasing the interest rate, integration of exchange rate, legalization of gold preservation, decreasing deficits in the public sectors, omission of subsidies in public enterprises, demobilization of half a million soldiers, omission of public investment plans, price deregulation and omission of public procurement system, law legislation on enterprises rights, deregulation of FDI, free international trade and establishing trade zones. Similarly, other countries in the region have also experienced positive developments.

Asian country's economic growth with the help of the foreign direct investment and the government green light could improve the living standards of the families and their consumption priorities. It could increase the demand for products and services by establishing the revenues in industrial, financial, and business. The emergence of Asian middle class households now means that accessing public services is not enough for them. Also, the quality of these services, along with issues such as health, education, tourism, automobiles, smart electronics, apartments - which is generally regarded by the government as its provider- are also important. So, under these circumstances, it seems this profitable market is going to be continued and getting much more attention on the part of foreign investors.

\section{References}

Ali, Shimelse \& Dadush, Uri. (2012). A new measure of the global middle class. Retrieved from https://voxeu.org/article/new-measure-global-middle-class

Amadeo, Kimberly. (2019). China's Economic Growth, Its Causes, Pros, Cons, and Future. Retrieved from https://www.thebalance.com/china-s-economic-growth-cause-pros-cons-future-3305478

Amin, Samir. (1976). Unequal Development: An Essay on Social Formation of Peripheral Capitalism. New York: The Harvester Press.

Amini, Armin \& Shokrollahi, Samira. (2012). Globalization and economic development in Vietnam. International Commerce, Economics and Policy, 03, No. 01, 161-205. Doi:10.1142/S1793993312400066

$\begin{array}{lllllll}\text { ASEAN. } & \text { (2017). ASEAN } & \text { Economic Integration } & \text { Brief. } & \text { Retrieved } & \text { from } \\ \text { https://asean.org/storage/2017/11/AEIB_2nd-edition.pdf. } & & & \\ \text { ASEAN. } & \text { (2017). } \quad A S E A N & \text { Economic } & \text { Integration } & \text { Brief. } & \text { Retrieved } & \text { from } \\ \text { https://asean.org/storage/2019/06/AEIB_5th_Issue_Released.pdf. } & & \end{array}$


ASEAN.(2018). ASEAN Business Guide: The Economy of ASEAN and The Opportunities They Present. Retrieved from https://assets.kpmg/content/dam/kpmg/la/pdf/2018/08/asean-business-guide2018.pdf.

ASEAN.. (2015). ASEAN: The EAC Is Here, Finally. UOB Global \& Markets Research. Retrieved from https://www.uobgroup.com/assets/pdfs/research/ASEAN-Focus_4q15.pdf.

ASEAN. (2018). ASEAN Investment Report: Foreign Direct Investment and the Digital Economy in ASEAN. Retrieved from https://asean.org/storage/2018/11/ASEAN-Investment-Report-2018-forWebsite.pdf.

ASEAN. (2018). ASEAN Statistical Yearbook. Retrieved from https://asean.org/?static_post=aseanstatistical-yearbook-2018.

Baran, Paul. (1958). the Political Economy of Growth. New York: Monthly Review Press doi: $10.1017 /$ S0003055400232267

Benson, Michaela. (2014). Trajectories Of Middle Class Belonging: The Dynamics of place Attachment and Classed Identities. Urban Studies, 51(14). doi:10.1177/0042098013516522

Brueckner, Markus, Dabla-Norris, Era, Gradstein, Mark, ... Daniel. (2017). The Rise of the Middle Class and Economic Growth in ASEAN. World Bank Policy Research Working Paper, 56 (8068), 48-58.

Cumings, Woo. (2007). The Role of Government in East Asian Economic Development. Comparative Institutional Analysis (2 ${ }^{\text {nd }}$ ed) Oxford Press. doi: 10.1093/acprof:oso/9780198294917.001.0001

Diaconu, Laura. (2014). The foreign direct investments in South-East Asia during the last two decades. Procedia Economics and Finance.doi: 10.1016/S2212-5671(14)00554-1

Duara, Prasenjit (2018). Nationalism and development in Asia. United Nations University World Institute for Development Economics Research. doi: 10.35188/UNU-WIDER/2018/537-4

Embong, A. (2002). State-led Modernization and the New Middle Class in Malaysia. United Kingdom, Palgrave Macmillan. doi: 10.1057/9781403914286

Eshe, Nelson. (2019). Inrich countries, the middle class is getting smaller and smaller, generation by generation. Retrieved from https://qz.com/1592826/the-middle-class-is-shrinking-generation-bygeneration/.

Fernandes, Leela. (2006). India's New Middle Class (Democratic Politics In An Era Of Economic Reform). University Of Minnesota Press.

Financier Worldwide Magazine. (2015). FDI in Asia. Retrieved from https://www.financierworldwide.com/fdi-in-asia\#.XZ3Qe2YlHIX.

Fouad Khater, Akram. (2001). Inventing Home (Emigration, gender \& The Middle Class in Lebanon, 18701920). University Of California.

Glazer, Nathan. (1999). Two Cheers for 'Asian Values' the national interest. Retrieved from https://nationalinterest.org/article/two-cheers-for-asian-values-514

Gold, Thomas. (1986). State and the Society in the Taiwan Miracle. New York.

Gottschlich, Pierre. (2011). Indias Middle Class: New Forms Of Urban Leisure, Consumption And Prosperity. Reviews: Arnold Bergstraesser Institute.

Hamel, Kristofer \& Tong, Baldwin. (2019). Look East instead of West for the future global middle class. Retrieved from https://oecd-development-matters.org/2019/05/07/look-east-instead-of-westfor-the-future-global-middle-class/.

Hassall, Graham. (1991). Nationalism and ethnic conflict in the Pacific islands. Retrieved from https://www.researchgate.net/publication/293737775_Nationalism_and_ethnic_conflict_i $\mathrm{n}$ _the Pacific islands

Hagen, Everett. (1986). The Economics of Development. Richard d Irwin.

Hawes, Gary \& Liu, Hong. (1993). Explaining the Dynamics of the Southeast Asian Political Economy: State Society, and the Search for Economic Growth. Cambridge University. 
Heffner, Heather. (2015). "A Dragon Risen From A Shallow Stream”: The South Korean Middle Class frame Through Narratives Of Loss, Progress And Return. Alternatives: Global, Locla And Political, 4O(1). doi:10.1177/0304375415581256

Hill, Hal. (2013). The Political Economy of Policy Reform: Insights from Southeast Asia. Asian Development Review, 30 (1), pp. 108-130. doi:10.2139/ssrn.2260123

Hsu, Sara. (2016). Economic Reform in Asia China, India, and Japan. United Kingdom, Edward Elgar Publishing.

Holcombe, Randall G. (2013); South Korea's economic future: Industrial policy, or economic democracy?. Journal of Economic Behavior \& Organization. United States of America, Elsevier, 88(C), p 3-13. doi: 10.1016/j.jebo.2011.07.021

Inkeles, Alex. (1974). Becoming Modern: Individual Change in Six Developing Countries. Social Forces, 55(2) Cambridge, Harvard University Press.

Islami, Saeed. (2014). Asia Minor Tigers. Quarterly Journal of Politics, Third Summer, 2016, No. 10, 19-35. Doi http://ensani.ir/fa/article.

International Growth Center. (2010). Economic Growth and Structural Change in South Asia: Miracle or Mirage? London, International Growth Centre. Retrieved from http://eprints.lse.ac.uk/36389/1/Economic_growth_and_structural_change_in_South_A sia.pdf.

Jabbour, Elias and Alexis, Dantas. (2017). the political economy of reforms and the present Chinese transition. Brazilian Journal of Political Econonny, 374). doi: 10.1590/010131572017v37n04a08

K. Spencer, Michael. (2019). The Middle Class is Shrinking. Retrieved from https://medium.com/utopiapress/the-middle-class-is-shrinking-c5fd0ea05af8.

Jinguo, Wang. (2000). The Role of Confucian Values in East Asian Development: Before and After the Financial Crisis. Journal of International and Area Studies. 71), pp. 115-135. doi jstor.org/stable/43107028

Jullens, John. (2014). Lessons from the East Asian Development Model.PwC. Retrieved from https://www.strategy-business.com/blog/Lessons-from-the-East-Asian-DevelopmentModel?gko $=60 f 9 c$

Keiichi, Tsunekawa \& Yasuyuki, Todo. (2019). Emerging States at Crossroads. Springer Singapore.

Kimura, Fukunari. (2011). Production Networks in East Asia: What we know so Far. Retrieved from https://www.researchgate.net/publication/228270241_Production_Networks_in_East_Asi a_What_We_Know_so_Far.

Kharas, Homi \&Gertz, Geoffery. (2010). Chinas Emerging Middle class (Beyond Economic Transformation). Washington DC, Brookings Institution Press.

Krause, Eleanor \& Sawhill, Isabel V. (2018). Seven reasons to worry about the American middle class. Retrieved from https://www.brookings.edu/blog/social-mobility-memos/2018/06/05/sevenreasons-to-worry-about-the-american-middle-class/.

Kwong Ko, Lap \& Tang, Tanzy. (2018). Economic Success in East Asia and in Hong Kong. Asian Business Research. July Press Pte. Ltd. Retrieved from https://www.researchgate.net/publication/324891465_Economic_Success_in_East_Asia_ and_in_Hong_Kong

Lajčiak, Milan. (2017). East Asian economies and their philosophy behind success: Manifestation of social constructs in economic policies. Journal of International Studies, 10(1), pp. 180-192. doi:10.14254/2071-8330.2017/10-1/13

Landsberg, Martin. (1979). Export-led Industrialization in the Third World. Review of Radical Political Economics. Sage Publications Inc. 
Leftwich, Adrian. (2000). States of Development: On the Primacy of Politics in Development. Polity. Lerner, Daniel. (1958). The Passing of Traditional Society: Modernizing the Middle East. Macmillan Pub Co.

McClelland, David. (1961). The Achieving Society. Martino Fine Books.

Mungiu-Pippidi, Alina \& Mindruta, Denis. (2002). Was Huntington Right? Testing Cultural Legacies and the Civilization Border. International Politics, 39(2), pp. 193-213. United States, Kluwer Law International. doi: 10.1057/palgrave.ip.8897387

Naqibzadeh, Ahmed \& Sadeghizadeh, Salman. (2009). Causes of Economic Development in Southeast Asia. Journal of Politics, 41(1), pp. 335-347. doi: https://jpq.ut.ac.ir/article_29737.html

Nath, S. K. (1962). The Theory of Balanced Growth. Oxford Economic Papers. England, Oxford University Press.

Nurkse, R. (1971). The Theory of Development and the Idea of Balanced Growth. Developing the Underdeveloped Countries, 7, pp. 115-128. London, Palgrave Macmillan.

Padilla, Hoang Thuy. (2012). Parental School Choices In Marked-Oriented School Systems: Why Middle Class Asian Immigrants Self-Select Into Specialized Academic Programs. United States, ProQuest LLD.

Pattison, Liz Bentley. (2016). Factors Explaining the Rapid Economic Growth of China In Recent Decades. England, Tutor2u. Retrieved from https://www.tutor2u.net/geography/reference/factorsexplaining-the-rapid-economic-growth-of-china-in-recent-decades.

Pham, Hung Hung. (2012). 'The Developmental State,' the evolving international economic order, and Vietnam. United Kingdom, University of Birmingham.

Pourrestami, Nahid. (2013). "Factors Affecting Economic Convergence in the East Asian Region”. Journal of Economic, 15(57), pp. 39-74. doi: http://joer.atu.ac.ir/article_1647.html

Raka, Ray. (2008). Indias New Middle Class: Democratic Politics In An Era Of Economic Reform. Contemporary Sociology, 372). doi:10.1177/009430610803700213

Rodan, Rosenstein P. N. (1961). Notes on the Theory of the 'Big Push'. Economic Development for Latin America London, Palgrave Macmillan.

Roughneen, Simon. (2019a). Has Asia's middle class creation peaked? Hong Kong, Asia Times Holdings Limited. Retrieved from https://www.asiatimes.com/2019/04/article/has-asias-middle-classcreation-peaked/.

Roughneen, Simon. (2019b). Southeast Asia bucks trend of sinking global foreign investment. Hong Kong, Asia Times Holdings Limited. Retrieved from https://asia.nikkei.com/Economy/Southeast-Asiabucks-trend-of-sinking-global-foreign-investment.

Sarel, Michael. (2006). Growth in East Asia: What We Can and What We Cannot Infer. IMF Working Paper, 95/98. International Monetary Fund.

Seriatos, Gerasimos. (2015). Foreign Direct Investment and the Chinese Economy: Theory and Impact. United States, City University of New York (CUNY) Academic Works.

Schrager, Allison. (2017). The good news about the hollowing out of America's middle class. Quartz Media, Inc. Retrieved from https://qz.com/1005068/the-upper-middle-class-is-the-new-middleclass/.

Schibotto, Emanuele. (2015). The importance of leadership for Asia's development. Geopolitica. Retrieved from https://www.geopolitica.info/importance-of-leadership/

Directorate-General of Budget, Accounting and Statistics Executive Yuan, Republic of China. (2018). Statistical Yearbook of the Republic of China. . Retrieved from https://eng.dgbas.gov.tw/public/data/dgbas03/bs2/yearbook_eng/Yearbook2017.pdf. 
Szakonyi, Mark. (2014). Asian Middle Class Growth Full Of Promise, Challenges.. New York, JOC Group Inc. Retrieved from https://www.joc.com/international-logistics/distribution-centers/asianmiddle-class-growth-full-promise-challenges_20141015.html

The Business Times. (2015). Middle class, Free trade, Investments and US exports. Retrieved from https://search.proquest.com/docview/1662720570?accountid=26226.

The Gold Coast Bulletin. (2012). Middle class and Tourism. Retrieved from https://search.proquest.com/docview/1124542233?accountid=26226.

The Nation. (2014). Middle class and Costs. Retrieved from https://search.proquest.com/docview/1562267782?accountid=26226.

The World Bank/China. (2017). China Economic Update - December 2017: Growth Resilience and Reform Momentum. World Bank. The World Bank Group. . doi: 10.1596/29059

Thomsen, Stephen. (1999). Southeast Asia: The Role of Foreign Direct Investment Policies in Development. OECD Working Papers on International Investment 1999/01. France, Organisation for Economic Co-operation and Development. doi: 10.1787/431857742281

Tökölyová, Tatiana. (1999). Transnationalism in the Pacific Region as a Concept of State Identity. Journal of Nationalism, 11(1). doi: 10.1515/jnmlp-2017-0001

Torll, Takashi. (2003). The Mechanism for State-Lead Creation of Malaysia's Middle classes: The Developing Economies.

Wang, Zhi \& Wei, Shang-Jin. (2009). Value Chains in East Asian Production Networks- An International Input-Output Model Based Analysis. Washington DC, U.S. International Trade Commission. Retrieved from https://usitc.gov/publications/332/EC200910C.pdf

Weber, Max. (2016). The Protestant Ethics and the Spirit of Capitalism. eBooks.com. Retrieved from https://www.ebooks.com/en-ua/95652307/the-protestant-ethic-and-the-spirit-ofcapitalism/weber-max.

Wessel, Margit Van. (2004). Talking About Consumption (How an Indian Middle Class Dissociates from Middle-Class Life). Cultural Dynamics, 16(1). Doi:10.1177/0921374004042752

Willige, Andrea. (2017). 5 charts that show what is happening to the middle class around the world. World Economic Forum. Retrieved from https://www.weforum.org/agenda/2017/01/5-chartswhich-show-what-is-happening-to-the-middle-class-around-the-world.

Wong, Peter. (2017). Made in Asia for Asia: How the rise of its middle class is remaking the world economy. South China Morning Post. Retrieved from https://www.scmp.com/comment/insightopinion/article/2087687/made-asia-asia-how-rise-its-middle-class-remaking-world.

United Nations. (2019). Special Economic Zones. World Investment Report 2019. New York, United Nations. Retrieved from https://unctad.org/en/PublicationsLibrary/wir2019_en.pdf.

Woodward, Ian. (2003). Divergent Narratives In The Imagining Of The home Amongst Middle Class Consumers (Aesthetics, Comfort And Symbolic Boundaries Of The Self And Home). Journal Of Sociology, 39(4). SAGE Journals. doi:10.1177/0004869003394005

Yusof, Ayisy. (2018). Malaysia's 2020 economic growth to be a tale of two halves: Analysts. New Strait Times. Retrieved from https://www.nst.com.my/business/2020/03/570879/malaysias-2020economic-growth-be-tale-two-halves-analyst 
